Corrigendum

\title{
Corrigendum to "Symptomatic Clitoral Neuroma within an Epidermal Inclusion Cyst at the Site of Prior Female Genital Cutting"
}

\author{
Dani Zoorob $\mathbb{D}^{1}{ }^{1}$ Thomas Klein $\mathbb{D}^{1},{ }^{1}$ Kristrun Kristinsdottir $\mathbb{D}^{1},{ }^{1}$ and Sonyoung Seo-Patel $\mathbb{D}^{2}$ \\ ${ }^{1}$ University of Toledo, Department of Obstetrics and Gynecology Academic Offices, 2142 N. Cove Blvd., Toledo, OH 43606, USA \\ ${ }^{2}$ ProMedica Health System, Women's Services, 2142 N. Cove Blvd., Toledo, OH 43606, USA \\ Correspondence should be addressed to Dani Zoorob; dzobgyn@gmail.com \\ Received 14 August 2020; Accepted 14 August 2020; Published 4 September 2020 \\ Copyright (C) 2020 Dani Zoorob et al. This is an open access article distributed under the Creative Commons Attribution License, \\ which permits unrestricted use, distribution, and reproduction in any medium, provided the original work is properly cited.
}

In the article titled "Symptomatic Clitoral Neuroma within an Epidermal Inclusion Cyst at the Site of Prior Female Genital Cutting" [1], the order of the second and third authors was reversed. The corrected author list is shown above.

\section{References}

[1] D. Zoorob, K. Kristinsdottir, T. Klein, and S. Seo-Patel, “Symptomatic clitoral neuroma within an epidermal inclusion cyst at the site of prior female genital cutting," Case Reports in Obstetrics and Gynecology, vol. 2019, Article ID 5347873, 3 pages, 2019. 